\title{
An Economic Study of Growth Dimension on Food Grains in India
}

\author{
K. S. Mohana Priya", R. Senthilkumar, R. Pangayar Selvi and C. Muralidharan
}

Department of Social Sciences, Agricultural College and Research Institute, Killikulam, India

*Corresponding author

\section{A B S T R A C T}

Ke y w o r d s
Compound growth
rate, Linear trend,
Food grain area,
Production and
Productivity

In Indian agriculture, food grain crops cover the dominant part of cropped area (65 per cent). India is continuously facing pressure on the demand side due to limited land availability, steady population growth and several other production constraints, which appear as obstacles for supply of food grains. In the present study, growth in area, production and productivity of food grains were estimated using the linear trend and compound growth function. To analyze performance of food grain production it is categorized into Pre- liberalization period (1960-61 to 1989-90) and post-liberalization period (1991-92 to 2019-20). It has revealed that post liberalization period has been characterized by decline in the growth rate of area, production and productivity of major staple food grains (rice and wheat) whereas, growth rate of area, production and productivity of coarse cereals and pulses increased after liberalization when compared to pre liberalization period. In the overall period, the compound growth rate of area, production and productivity of total food grains was 0.01 per cent, 0.98 per cent and 0.97 per cent respectively. Further, it was found that there was a decline in area while the production and productivity had increased to a considerable extent in the overall period.

\section{Introduction}

India is home to many cereal and pulse varieties that are largely consumed domestically. Food grains shall be whole or broken kernels of cereals, millets and pulses intended for human consumption. Food grain basket comprises of rice, wheat, coarse cereals and pulses. These crops are grown in both rabi (winter) and kharif (summer) season. Cereal grains are the single most important source of calories for the majority of the world's population. More than 50 per cent of the world's daily caloric intake is derived directly from cereal grain consumption (Ahmad, 2015). India's food security essentially depends upon rice and wheat production. Rice is the predominant food grain crop in India that is widely cultivated in almost all parts of the country. India was ranked second in area under rice cultivation contributing nearly 22 per cent of global rice production and also ranked second among wheat producing countries of the world. Coarse cereals are a group of six cereals namely jowar, bajra, maize, ragi, barley and millets grown mainly in rainfed areas (Mittal, 2016). Growth of food grains production was important for sustainable food and nutrition security of the growing 
population of India (Mary, 2018). Over the past 70 years, several policy initiatives taken by the Government of India had brought changes in agricultural sector in cropping pattern, production and productivity of food grains. The initiation of economic reforms in India in 1991 brought about major changes in the macroeconomic policy frame- work of the planned economy that existed in India during 1950-51 to 1990-91 (Bhalla, 2009). With liberalization, private participation in all aspects of agriculture including seed, mechanization, plant protection, plant nutrition and marketing had taken place.

The policy led to the promotion of exports and the introduction of improved offshore cultivation technologies leading to rapid agricultural growth. This has resulted in the shifting of cropping pattern from food grain crops towards high value crops like fruits and vegetables and export oriented crops (Selvi, 2014). The agricultural sector in India has not experienced the expected benefits and significant growth from trade liberalization. According to Mishra (2015), after liberalization, the food grain production though increased but at a very lower rate as compared to the growth rate before Liberalization. Several research reports revealed that the area under food grain crop cultivation has been declining and indicated that the cultivation of non-food grain crops has been increasing. This shift in cropping pattern to commercial crops was due to remunerative prices being offered and better market accessibility provided to growers.

In this study, the specific objective is to asses the trend, growth rates in area, production and productivity of major food grain crops in India before and after liberalization. This study mainly concentrated on crops like rice, wheat, coarse cereals and pulses as India contributed major share in these types of food grains in the world.

\section{Materials and Methods}

In order to conduct the study, the secondary data on area, production and productivity of rice, wheat, coarse cereals, pulses and total food grains were collected for a period of 60 years (1960-61 to 2019-20) from published sources like Agricultural Statistics at a Glance (2018) and Indiastat. The overall period was split into two periods as pre liberalization period (1960-61 to 1989-90) and post liberalization period (1990-91 to 2019-20) to study the trend in area, production and productivity before and after liberalization. The pattern of food grains was studied using mean and coefficient of variation. To measure the past performance of the economic variables and to describe the trends in those variables over time growth rates were used. Growth rate is generally expressed in two forms, viz., linear and compound (Acharya, 2012). Trend in area, production and productivity has been estimated by using linear growth rate technique represented as follows:

$y=a+b t$

Compound growth rates (CGR) of area, production and productivity were estimated by fitting the time- series data in exponential function of the following form:

$\mathrm{Y}=\mathrm{ab} \mathrm{b}^{\mathrm{t}}$

Where

$\mathrm{Y}=$ Area/productivity/production of major food grains as the dependent variable

$\mathrm{t}=$ Time variable (year) as independent variable

$\mathrm{a}=$ Intercept

$\mathrm{b}=$ Regression coefficient

The exponential function was transformed to the semilog model and estimated using 
ordinary least square (OLS). In logarithmic form:

$\log \mathrm{y}=\log \mathrm{a}+\mathrm{t} \log \mathrm{b}$

$\log \mathrm{y}=\mathrm{A}+\mathrm{B} \mathrm{t}$

Where, $\mathrm{A}=\log \mathrm{a} ; \mathrm{B}=\log \mathrm{b}$

Percent compound growth rate " $\mathrm{r}$ " can be computed as:

$r=[($ Antilog of $b)-1] x 100$

To examine the stability in productivity of food grains before and after liberalization, coefficient of variation (CV) was estimated.

$C V=\frac{\sigma}{\mu}$

where, $\sigma_{\mathrm{x}}=$ Standard deviation of $\mathrm{X}$

$X=$ Mean of $X$

\section{Results and Discussion}

\section{Growth dimensions in area, Production and Productivity}

As it could be seen from table 1, the average area under total food grains was 124.37 million ha in the pre liberalization period, 123.14 million ha during the post liberalization period and 123.76 million ha during the overall study period. The area under cultivation of food grain has declined, indicating an increase in the cultivation of non-food grain crops (Navjit, 2011). The mean area under rice (43.40 million ha), wheat (27.47 million ha) and pulses (23.45 million ha) was highest in the post liberalization period when compared to other periods. The fluctuations in growth in terms of area under total food grains were low during pre liberalization (3.44\%), post liberalization $(2.26 \%)$ and overall period $(2.93 \%)$ indicating that the growth in terms of area was stable. Similarly, the coefficient of variation for area under rice, wheat, coarse cereals and pulses was low during all the periods indicating growth was stable.

In case of production of food grains, it could be observed from table 1 that the average production of total food grains increased from 121.54 million tonnes in the pre liberalization period to 218.66 million tonnes during the post liberalization period and 170.10 million tonnes during the entire study period though the mean area under total food grains declined during the post liberalization period. The mean production of rice, wheat, coarse cereals and pulses was highest in the post liberalization period. Agriculture production increased by using the productivity enhancing inputs like chemical fertilizers, access to irrigation and choice of crops or cropping pattern (Chand, 2011). The coefficient of variation for production of total food grains was low during post liberalization (14.98\%) than pre liberalization $(23.42 \%)$ and overall period $(33.91 \%)$ indicating that the growth in terms of production was not stable in the pre liberalization and overall period. Similarly, the growth in terms of production or rice and wheat was not stable in the pre liberalization and overall period and for pulses, production was not stable in the post liberalization period. Growth in production was almost stable for coarse cereals in all the periods.

Productivity is measured as the amount of crop produced per unit area of land, also known as productivity. From table 1, it could be observed that the average productivity of total food grains increased from $972.48 \mathrm{Kg} / \mathrm{ha}$ in the pre liberalization period to 1773.11 $\mathrm{Kg} / \mathrm{ha}$ during the post liberalization period and $1372.80 \mathrm{Kg} / \mathrm{ha}$ during the entire study period. The mean productivity of rice, wheat, coarse cereals and pulses was higher in the 
post liberalization period when compared to pre liberalization and overall period. However the rate of increase was lower in case of pulses, the mean productivity of coarse cereals was almost doubled in the post liberalization period.

The coefficient of variation for productivity of total food grains was low during post liberalization $(13.66 \%)$ than pre liberalization $(21.18 \%)$ and overall period (33.61\%) indicating that the growth in terms of productivity was not stable in the pre liberalization and overall period. Fluctuations were higher during the overall study period for rice, wheat and coarse cereals. For pulses, the coefficient of variation for productivity was low in all the periods indicating that the growth in terms of productivity was stable.

\section{Compound growth rate of area, Production and Productivity}

As depicted in fig. 1, compound growth rate of area under total food grains $(0.13 \%)$, rice $(0.27 \%)$ and wheat $(1.02 \%)$ was highest during the pre liberalization period when compared to other periods. Wheat and rice showed the same pattern of growth in all the periods that is highest in the pre liberalization period followed by overall period and post liberalization period.

The possible reason for slowing down growth was attributed that during the post liberalization period was a visible decline in investment in irrigation and other rural infrastructure (Bhalla, 2009). The compound growth rate for area under pulses $(0.27 \%)$ was highest in the post liberalization period and for coarse cereals, compound growth rate was negative during all the periods. It might be due to the importance given to the cultivation of these crops in that period.
As portrayed in fig. 2 in the pre liberalization period, production under total food grains, rice, wheat expanded at a compound growth rate of $1.25 \%, 1.24 \%$ and $2.54 \%$ higher than post liberalization and overall period. The growth was positive and significant in all the periods. This is in support with (Navjit, 2011) reported that after liberalization, food grain production increased but at a much lower rate than before liberalization. The growth rate was highest in pre liberalization period for rice $(1.24 \%)$ and wheat $(2.54 \%)$ whereas growth rate was highest in post liberalization period for coarse cereals $(0.71 \%)$ and pulses $(0.75 \%)$ when compared to other periods. Rice, wheat and total food grains exhibited a similar pattern of growth highest in the pre liberalization period followed by overall and post liberalization period. While coarse cereals and pulses showed a similar pattern growth rate highest in the post liberalization followed by overall and pre liberalization period.

As it could be observed from the fig. 3, during the pre liberalization period, the productivity under total food grains, rice and wheat expanded at a compound growth rate of 1.11 $\%, 0.97 \%$ and $1.50 \%$ higher than the post liberalization period and overall period. The growth was positive and significant in all the periods. The growth rate was higher in post liberalization period for coarse cereals and pulses as contrary to rice, wheat and total food grains.

The increase in productivity might be resulted from advances in technology, irrigation and the conversion of crops with low productivity to high value products (Acharya, 2009). Alike compound growth rate of production, rice, wheat and total food grains exhibited a similar pattern of growth whereas coarse cereals and pulses showed a similar pattern of growth rate. 
Table.1 Growth dimensions in area, production and productivity of major food grains in India

\begin{tabular}{|c|c|c|c|c|c|c|c|}
\hline \multirow[t]{2}{*}{ Crops } & \multirow[t]{2}{*}{ Period } & \multicolumn{2}{|c|}{ Area } & \multicolumn{2}{|c|}{ Production } & \multicolumn{2}{|c|}{ Productivity } \\
\hline & & $\begin{array}{c}\text { Mean } \\
\text { (Million } \\
\text { ha) }\end{array}$ & C.V (\%) & $\begin{array}{l}\text { Mean } \\
\text { (Million } \\
\text { tonnes) }\end{array}$ & C.V (\%) & $\begin{array}{c}\text { Mean } \\
\text { (Kg/ha) }\end{array}$ & C.V (\%) \\
\hline \multirow[t]{3}{*}{ Rice } & Pre liberalization & 39.03 & 5.40 & 49.55 & 24.57 & 1257.74 & 19.49 \\
\hline & Post liberalization & 43.40 & 2.52 & 91.28 & 13.01 & 2101.15 & 12.14 \\
\hline & Overall period & 41.22 & 6.70 & 70.41 & 34.36 & 1679.44 & 29.33 \\
\hline \multirow[t]{3}{*}{ Wheat } & Pre liberalization & 20.17 & 18.40 & 32.22 & 41.29 & 1530.22 & 27.03 \\
\hline & Post liberalization & 27.47 & 7.84 & 76.53 & 17.03 & 2768.19 & 9.90 \\
\hline & Overall period & 23.82 & 19.96 & 54.37 & 47.62 & 2149.20 & 33.27 \\
\hline \multirow{3}{*}{$\begin{array}{l}\text { Coarse } \\
\text { cereals }\end{array}$} & Pre liberalization & 42.27 & 7.20 & 28.27 & 11.49 & 672.22 & 16.62 \\
\hline & Post liberalization & 28.76 & 10.04 & 35.69 & 16.41 & 1267.33 & 24.87 \\
\hline & Overall period & 35.52 & 20.93 & 31.98 & 18.79 & 969.78 & 39.28 \\
\hline \multirow{3}{*}{$\begin{array}{c}\text { Total } \\
\text { Pulses }\end{array}$} & Pre liberalization & 22.89 & 4.24 & 11.51 & 12.69 & 501.85 & 10.32 \\
\hline & Post liberalization & 23.45 & 9.44 & 15.18 & 22.13 & 641.52 & 12.79 \\
\hline & Overall period & 23.17 & 7.40 & 13.35 & 23.72 & 571.69 & 17.13 \\
\hline \multirow{3}{*}{$\begin{array}{l}\text { Total } \\
\text { Food } \\
\text { grains }\end{array}$} & Pre liberalization & 124.37 & 3.44 & 121.54 & 23.42 & 972.48 & 21.18 \\
\hline & Post liberalization & 123.14 & 2.26 & 218.66 & 14.98 & 1773.11 & 13.66 \\
\hline & Overall period & 123.76 & 2.93 & 170.10 & 33.91 & 1372.80 & 33.61 \\
\hline
\end{tabular}

Source: Calculated by author using data from Agricultural Statistics at a Glance, 2018

Table.2 Linear trend in area, production and productivity of major food grains in India

\begin{tabular}{|c|l|c|c|c|}
\hline Crops & \multicolumn{1}{|c|}{ Period } & Area & Production & Productivity \\
\hline \multirow{2}{*}{ Rice } & Pre liberalization & $0.24^{* *}$ & $1.41^{* *}$ & $28.20^{* *}$ \\
\cline { 2 - 5 } & Post liberalization & $0.03^{\mathrm{NS}}$ & $1.36^{* *}$ & $30.13^{* *}$ \\
\cline { 2 - 5 } & Overall period & $0.15^{* *}$ & $1.51^{* *}$ & $30.72^{* *}$ \\
\hline \multirow{3}{*}{ Wheat } & Pre liberalization & $0.44^{* *}$ & $1.65^{* *}$ & $50.85^{* *}$ \\
\cline { 2 - 5 } & Post liberalization & $0.25^{* *}$ & $1.54^{* *}$ & $30.81^{* *}$ \\
\cline { 2 - 5 } & Overall period & $0.28^{* *}$ & $1.63^{* *}$ & $44.60^{* *}$ \\
\hline \multirow{2}{*}{$\begin{array}{c}\text { Coarse } \\
\text { cereals }\end{array}$} & Pre liberalization & $-0.35^{* *}$ & $0.25^{* *}$ & $12.28^{* *}$ \\
\cline { 2 - 5 } & Post liberalization & $-0.34^{* *}$ & $0.61^{* *}$ & $37.07^{* *}$ \\
\cline { 2 - 5 } & Overall period & $-0.46^{* *}$ & $0.31^{* *}$ & $22.69^{* *}$ \\
\hline \multirow{2}{*}{ Total } & Pre liberalization & $0.04^{\mathrm{NS}}$ & $0.09^{* *}$ & $3.13^{*}$ \\
\cline { 2 - 5 } Pulses & Post liberalization & $0.18^{* *}$ & $0.33^{* *}$ & $8.23^{* *}$ \\
\cline { 2 - 6 } & Overall period & $0.04^{* *}$ & $0.15^{* *}$ & $5.29^{* *}$ \\
\hline \multirow{2}{*}{ Total Food } & Pre liberalization & $0.36^{* *}$ & $3.41^{* *}$ & $24.76^{* *}$ \\
\cline { 2 - 6 } grains & Post liberalization & $0.12^{\mathrm{NS}}$ & $3.83^{* *}$ & $29.05^{* *}$ \\
\cline { 2 - 6 } & Overall period & $0.03^{\mathrm{NS}}$ & $3.60^{* *}$ & $28.97^{* *}$ \\
\hline
\end{tabular}

Source: Agricultural Statistics at a Glance, 2018

Note: ** indicates significance at $1 \%, *$ Indicates significance at $5 \%,{ }^{\text {NS }}$ indicates Not significant 
Fig.1 Compound growth rate in area of major total food grains in India

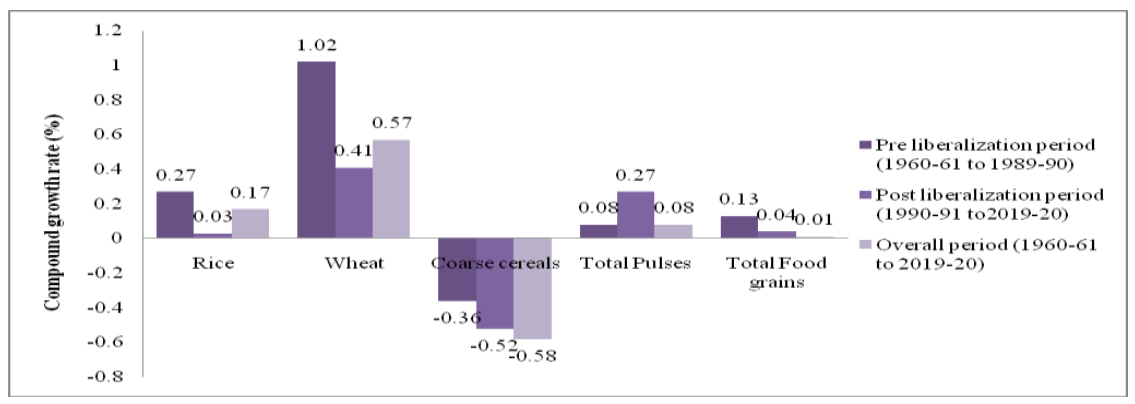

Fig.2 Compound growth rate in production of major total food grains in India

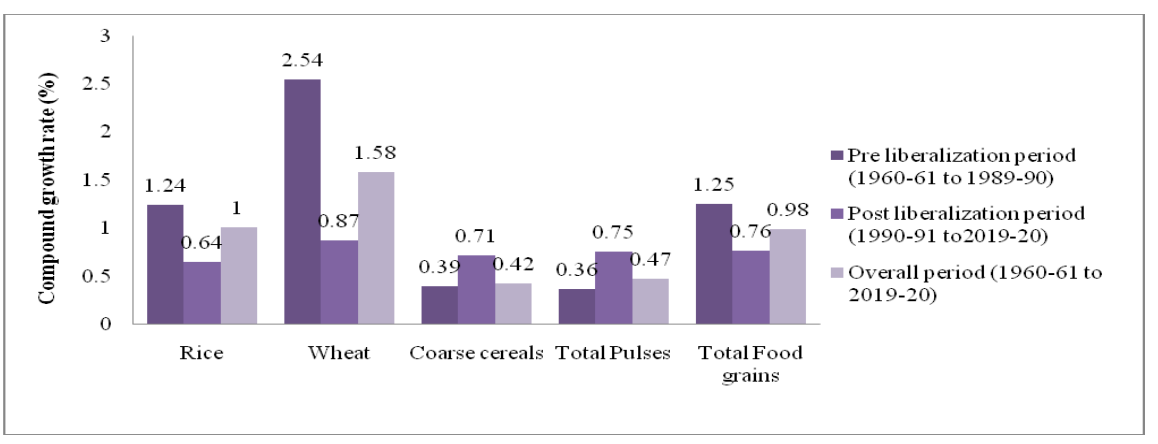

Fig.3 Compound growth rate in productivity of major total food grains in India

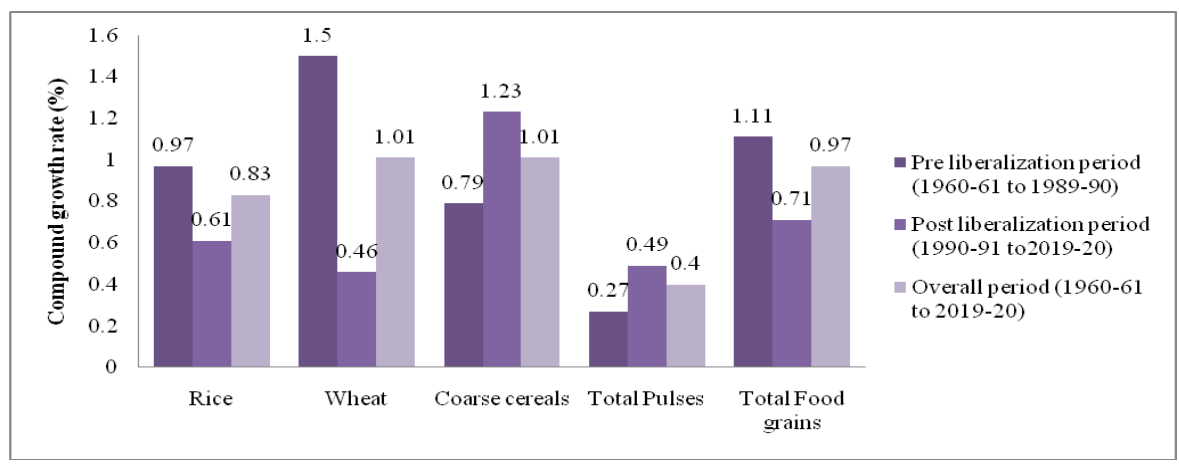

Fig.4 Trend in area of major total food grains in India

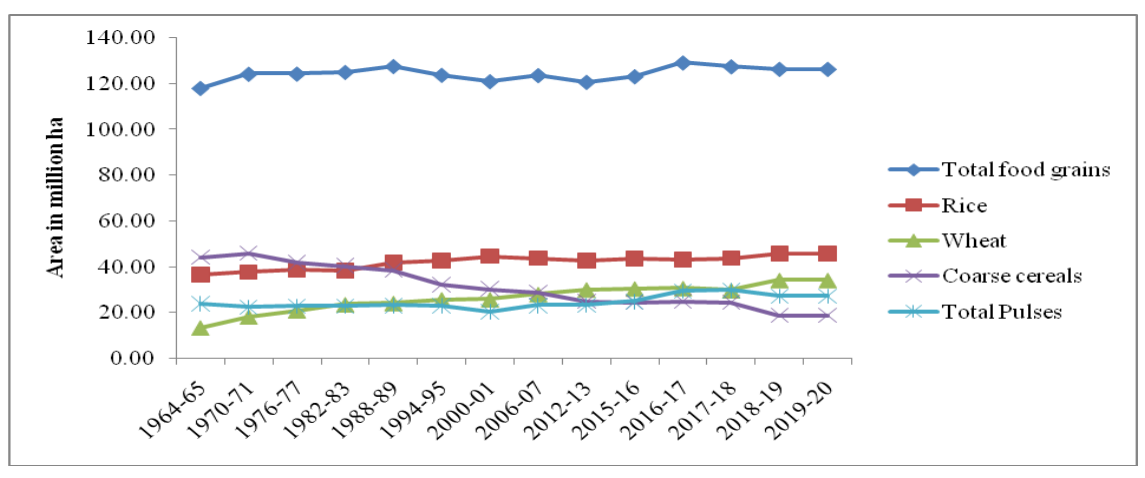


Fig.5 Trend in production of major total food grains in India

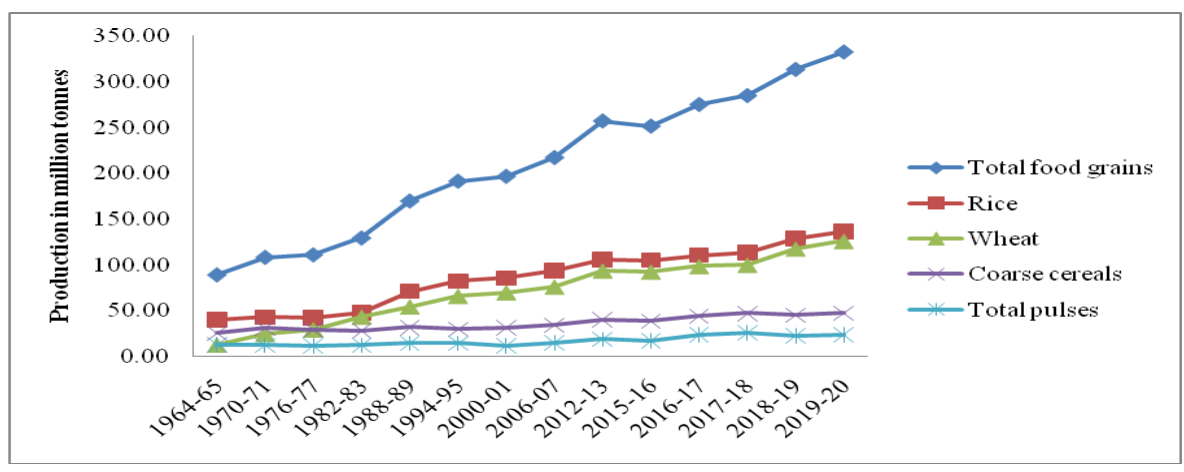

Fig.6 Trend in productivity of major total food grains in India

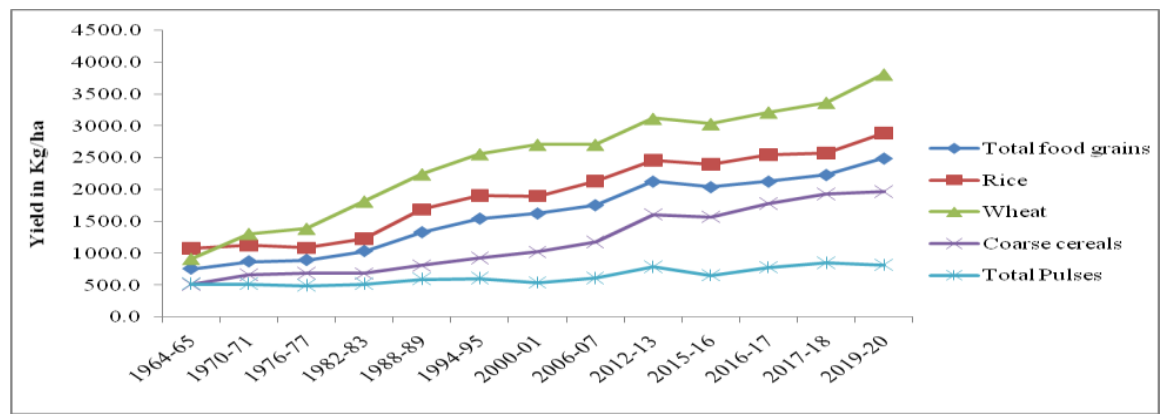

\section{Linear trend in area, production and productivity}

The trend analysis of area, production and productivity of major food grains has been worked out and presented in table 2. A significant positive trend for area under total food grains (0.36) and rice (0.24) was observed in the pre liberalization period and it was not significant in the remaining periods for total food grains. But for rice a significant positive trend (0.15) was observed in the overall period and not significant at post liberalization period. A significant positive trend for area under wheat was observed in all periods. Wheat showed a considerable growth of area in the pre liberalization period and the main reason for this increase was shift in area from coarse grain production to wheat production in the pre liberalization period. The trend analysis of coarse cereals showed significant declining trend in area in all the three periods (Fig. 4). The regression coefficient for pulses was significant and highest in the post liberalization period $(0.18)$ and not significant in the pre liberalization period (0.04). A significant positive trend for area under total pulses was observed in the post liberalization period (0.18) and overall period (0.04) whereas not significant at pre liberalization period.

As depicted in table 2 and fig. 5, we could observe significant positive trend for production of rice, wheat, coarse cereals, total pulses and total food grains in all the periods. The regression coefficient for production was higher in the post liberalization period for coarse cereals (0.61), pulses (0.33) and total food grains (3.83) when compared to pre liberalization and overall period. The regression coefficient for production was higher in the pre liberalization period for rice (1.41) and wheat (1.65). The reason for this increasing trend in production may be attributed to the availability of good quality 
seeds of high yielding varieties, expansion of irrigation facilities, uses of higher doses of fertilizer and increase in a relative profitability of the crop. The production and productivity of the different food grain crops have increased during the period under review due to the combine effects of area and productivity (Sharma, 2013).

As it could be inferred from the table 2, that significant positive trend was observed for productivity of rice, wheat, coarse cereals, total pulses and total food grains in all the periods. But the regression coefficient for total food grains was 24.76 , lowest in the pre liberalization period when compared to other periods. In this period, despite a greater availability of key inputs like fertilizers, high yielding varieties of seeds and water, the agricultural sector began to experience diminishing trends, since enough attention had not been paid to the efficiency of their use (Wasim, 2011). The regression coefficient for productivity was higher in the post liberalization period for rice (30.13), coarse cereals (37.07) and pulses (8.23) when compared to pre liberalization and overall period whereas the regression coefficient for productivity was higher in the pre liberalization period for wheat (50.85) when compared to other periods. Even though there was a decline in mean area, production and productivity were increased. This improvement in productivity can be attributed mainly due to adoption of high yielding varieties of seeds by the farmers, expansion of irrigation facilities and use of higher doses of fertilizer.

In conclusion the growth dimensions have been estimated for total food grains in terms of area, production and productivity. In the pre liberalization period (1960-61 to 198990), the mean area under food grain crops was higher when compared to other periods. In this period, rice and wheat occupied a major share in area. Fluctuations in production and productivity were higher in this period while the area was stable. The compound growth rates of area, production and productivity of rice, wheat was highest in pre liberalization period when compared to other periods. Linear trend analysis of total food grains showed significant increasing trend in area, production and productivity. In the post liberalization period (1990-91 to 2019-20), there was a decline in area under total food grains. Though the area under total food grains decreased the area under coarse cereals and pulses were increased. After liberalization, greater importance was shown to increase the production of coarse cereals and pulses. Mean production and productivity of rice, wheat, coarse cereals and pulses were increased due to wide spread use of technologies. The compound growth rates of area, production and productivity of rice, wheat and total food grains were lowest in post liberalization period when compared to other periods as contrary to coarse cereals and pulses. The coefficient of variation for area, production and productivity under total food grains showed that the growth was stable in post liberalization period (Fig. 6).

In the overall period (1960-61 to 2019-20), the compound growth rate of area was very low whereas the growth rate of production and productivity was high when compared to post liberalization period. Increasing trend was observed for area, production and productivity of total food grains. Trend analysis and compound growth rate showed that the area under coarse cereals was declining continuously. It could be concluded that the increasing compound growth rate of productivity have an positive impact on the growth rate of production and the decrease in area is offset by increasing trend in growth rate of productivity. The analysis revealed that though the area decreased, production and productivity increased for all food grain 
crops. The food grain productions need to be paid attention for their sustainability in area, production and productivity to feed the ever growing population.

\section{References}

Acharya, Saraswati Poudel, et al.2012. "Growth in Area, Production and Productivity of Major Crops in Karnataka." Karnataka Journal of Agricultural Sciences 25.4

Acharya, Shabd S. 2009."Food Security and Indian Agriculture: Policies, Production Performance and Marketing Environment." Agricultural Economics Research Review 22: 1-19.

Ahmad, Isah Musa, et al.2015. "Trend of Area, Production and Productivity of Major Cereals: India and Nigeria Scenario." Research Journal of Agriculture and Forestry Sciences3.2: 10-15.

Bhalla, G S, and Gurmail Singh.2009 "Economic Liberalization and Indian Agriculture: A Statewise Analysis." Economic \& Political Weekly xliv 52

Chand, Ramesh, P A Lakshmi Prasanna, and Aruna Singh. 2011. "Farm Size and Productivity: Understanding the Strengths of Smallholders and Improving Their Livelihoods." Review of Agriculture XLVI.26

Halawar, S. V.2019. "The Trend Analysis of Majortotal food grains in India." International Journal of Current Microbiology and Applied Sciences 8.03: 353-60.
Mary, R.M. Catherin Mehala, and P.C. Jose Paul.2018 "Performance of Food Grain Production in India." EPRA International Journal of Economic and Business Review 6.8

Mittal, Parul, and Shiksha.2016."Trends intotal food grains Production: A Study of Pre- Reforms Period in India." Pacific Business Review International 8.10

P., Mishra, et al., 2015."Study of Instability and Forecasting of Food Grain Production in India." International Journal of Agriculture Sciences 7.3

Selvi, R. Pangayar, S. Murali Gopal, and B. Swaminathan.2014. "Structural Changes in the Growth Dimensions of Maize (Zea mays L.) During PostGreen Revolution and PostLiberalization Periods of Indian Agriculture." Trends in Biosciences 7.20

Sharma, Amod.2013. "Trends in Area, Production and Productivity of Food Grain Crops: An Overview." Economic Affairs58.1

Singh, Navjit. 2011."Indian Agriculture: Before and after Economic Reforms." European Journal of Business and Management 3.4.

Wasim, Mohammad Pervez.2007. "Contribution of High-Productivity Varieties Seeds to Major Food Crops Production, Productivity and Area in Punjab - Pakistan." Indus Journal of Management \& Social Sciences 1.1: 46-52.

\section{How to cite this article:}

Mohana Priya, K. S., R. Senthilkumar, R. Pangayar Selvi and Muralidharan, C. 2020. An Economic Study of Growth Dimension on Food Grains in India. Int.J.Curr.Microbiol.App.Sci. 9(11): 308-316. doi: https://doi.org/10.20546/ijcmas.2020.911.037 